\title{
Pentingnya Nilai Persatuan Perpektif Al-Quran Surah Al-Imran Ayat 103 dalam Mengatasi Pandemi Covid-19
}

\author{
Mukhtar \\ Prodi Manajemen Pendidikan Islam, STAI Sangatta Kutai Timur \\ Email: tarkik.muchtar6@gmail.com
}

Tutik Hamidah

Universitas Islam Negeri Malang

Email: hamidah.ansori@gmail.com

Naskah diterima: 11 Mei 2021, direvisi: 27 Juni 2021, disetujui: 30 Juni 2021

\begin{abstract}
This study aims to analyze the values and spirit of unity and the prohibition of division and is taught by Islam, in Surah Al-Imran verse 103. The methodology of this research uses the liblary research method. Based on the interpretations of Ibn Kasir, Al Misbah and Al Qurtubi, explaining the importance of unity so that there is a "terrible" threat if it is violated (hostility/divorce). This indicates the importance of unity in life. Our scholars and founding fathers have also reminded us of the importance of unity. Departing from the importance of the value and spirit of unity, in the context of handling the spread of covid-19, especially in Indonesia, values and the spirit of unity need to be instilled in every heart because the value and spirit of unity has been taught for a long time and there are many examples of success due to the value of unity. This study focuses more on the study of interpretations (Ibn Kasir, Al Misbah, and Al Qurtubi) about surah Al-Imran verse 103 and is associated with the arguments and texts that are relevant to the values of unity. The methodology of this research is descriptive method, in Surah Al Imran verse 103 emphasizes that the existing values of unity can be implemented in dealing with the COVID-19 pandemic, including framing unity in faith, uniting in obedience, and uniting in warding off hoaxes \& self-control.
\end{abstract}

Keywords: Surah Al Imran: 103; Unity; The Covid-19 Pandemic

\begin{abstract}
Abstrak
Penelitian ini bertujuan untuk menganalisis nilai-nilai dan semangat persatuan dan larangan perpecahan dan diajarkan oleh Islam, dalam surah Al-Imran ayat 103. Metodologi penelitian ini menggunakan metode liblary research. Berdasarkan tafsir Ibnu Kasir, Al Misbah dan Al Qurtubi, menjelaskan bagaimana pentingnya persatuan hingga ada ancaman yang "mengerikan" apabila hal tersebut dilanggar (permusuhan/ bercerai-berai). Hal tersebut mengindikasikan pentingnya persatuan dalam kehidupan. Para ulama dan founding father kita juga telah mengingatkan tentang betapa pentingnya persatuan. Berangkat dari pentingnya nilai dan semangat persatuan, dalam konteks penanganan merebaknya covid-19, khususnya di Indonesia, nilai nilai dan semangat persatuan perlu ditanamkan ke setiap sanubari karena nilai dan semangat persatuan tersebut telah lama diajarkan dan banyak contoh
\end{abstract}


keberhasilan akibat nilai persatuan. Kajian ini lebih memfokuskan kepada kajian tafsir (Ibnu Kasir, Al Misbah, dan Al Qurtubi) tentang surah Al-Imran ayat 103 dan dikaitkan dengan dalil-dalil dan teks teks yang relevan dengan nilai-nilai persatuan.Metodologi penelitian ini adalah metode deskriptif, dalam surah Al Imran ayat 103 menegaskan bahwa nilai nila persatuan yang ada dapat diimplementasikan dalam dalam menangani pandemic covid-19, diantaranya membingkai persatuan dalam keimanan, bersatu dalam aras ketaatan, dan bersatu dalam menangkal hoax \& pengendalian diri.

Kata Kunci: Surah Al Imran; 103; Persatuan; Pandemi Covid-19

\section{A. Pendahuluan}

Lebih dari satu tahun sejak diumumkannya secara resmi oleh Pemerintah Indonesia tentang kemunculan penyakit mematikan corona virus deserse (Covid-19) pada Maret 2020 lalu ${ }^{1}$, sampai saat ini pandemik tersebut seolah tidak mau hengkang dari bumi Indonesia, malah sebaliknya jumlah kasus positive akibat virus covid-19 dari waktu ke waktu kian meningkat. Berdasarkan data Komite Penanganan Covid-19 dan Pemuliahan Ekonomi Nasional tertanggal 1 Januari 2021, jumlah terkonfirmasi positif mencapai 751.270. Data tersebut jika dibandingkan dengan data hari sebelumnya mengalami peningkatan sebanyak 8.072 kasus terkonfirmasi positif. Demikian pun dengan kasus meninggal akibat covid-19, tertanggal 1 Januari 2020 sebanyak 22.239 kasus, meningkat sebanyak 191 jiwa dibandingkan hari sebelumnya ${ }^{2}$, bahkan kasus tersebut kian mengkhawatirkan dengan terus meningkatnya jumlah kasus terkonfirmasi yang mencapai 1.713.684 pada 9 Mei 2021.

Pandemik yang telah "memporak porandakan" tatanan kehidupan, mulai dari struktur sosial, kesehatan hingga mental sampai saat ini terus dan terus membayangi serta "merepotkan" banyak Negara, bahkan hampir seluruh dunia. Penyakit yang tibaa tiba datang bahkan tanpa gejala, membuat banyak Negara terus berjibaku untuk melawannya, termasuk Indonesia. Untuk mengatasi itu, Indonesia berupaya untuk memutus jaringan penyebarannya, mulai dari pemenuhaan pelengkapan Alat Pelindung Diri (APD) dan bantuan tunai bagi masyarakat terdampak covid-19 hingga Presiden Joko Widodo menghimbau masyarakat untuk melakukan sosial distancing dengan menerapkan belajar, bekerja, dan beribadah dari rumah $^{3}$ serta himbauan $3 \mathrm{M}$ (mencuci tangan, memakai masker, menjaga jarak). Anjuran ini kemudian dikuatkan dengan dengan cara melakukan

\footnotetext{
${ }^{1}$ https://nasional.kompas.com/read/2020/03/09/05280011/kronologi-dan-urutan-munculnya-6-orangpositif-virus-corona-di-indonesia?page=all, diakses tanggal 1 Januari 2021.

${ }^{2}$ https://covid19.go.id/berita/hari-pertama-tahun-2021-kesembuhan-terus-meningkat-menjadi-617936orang, diakses 1 Januari 2021

${ }^{3}$ Selfie Miftahul Jannah, Antisipasi Corona, Jokowi Sebut Kerja, Belajar \& Ibadah dari Rumah. Available at: https://tirto.id/antisipasi-sebut-kerja-belajar-ibadah-dari-rumah-eFfr, diakses 24 Desember 2020.
} 
Pembatasan Sosial Berskala Besar (PSBB) di berbagai daerah melalui Peraturan Pemerintah Nomor 20 Tahun 2020 tentang Pembatasan Sosial Berskala Besar. Dalam PSBB tersebut, masyarakat dibatasi melakukan aktifitas tidak penting di luar rumah, pembelajaran dan kerja pemerintahan dilakukan dari rumah, perhotelan, pariwisata dan sebagainya ditutup guna membatasi penyebaran covid-19. Namun uapaya upaya tersebut nampaknya belum menuai hasil yang maksimal, pasalnya jumlah kasus terkonfirmasi positif covid-19 dari waktu ke waktu terus meningkat yang diakibatkan oleh banyak hal.

Dikutip dari Leo Agustino tentang penanganan wabah covid-19, sulitnya menekan penyebaran covid-19 diakibatkan oleh banyak hal, diantaranya: (1) Narasi narasi negativ dari pejabat pemerintah yang mencerminkan ketidakseriusan dalam menganalisa perkembangan saat awal kemunculan covid-19 di Wuhan, (2) Kurang baiknya komunikasi dan koordinasi antar stakeholders, hal ini nampak dari berbagai kebijakan antara pemerintah pusat dan daerah yang tidak sinergi, (3) warga acuh/abai terhadap himbauan pemerintah, hal ini nampak dari banyaknya orang berkumpul di tempat tempat keramaian, seperti Caffe, Mall, Bioskop, atau tempat tempat yang dilarang saat pelaksanaan PSBB. Selain itu, hal lainnya, banyak masyarakat yang tidak mematuhi untuk memakai masker dan mencuci tangan saat keluar rumah serta akibat kebutuhan hidup yang mengharuskan keluar rumah ${ }^{4}$. Mirisnya, berdasarkan survei yang dilakukan Badan Pusat Statistik, sebanyak 55\% masyarakat tidak patuh terhadap protokol kesehatan akibat tidak adanya sanksi serta kata "kurang" dan "kesadaran" yang sering menjadi alasan orang tidak mematuhi ${ }^{5}$.

Kata "kurang" dan "kesadaran" yang menjadi faktor ketidakpatuhan masyarakat akan protokol kesehatan temuan BPS, nampaknya sangat relevan jika dikaitkan dengan statemen Kabareskrim Polri Komjen Listyo Sigit Prabowo yang menyebut kerumunan demo omni buslow, kampanye pilkada dan kerumunan penjemputan Habib Riziq menjadi penyebab meningkatnya jumlah kasus penambahan pasien covid-19. ${ }^{6}$ Selain itu, ketidak patuhan akibat "kurang" dan "kesadaran" juga terlihat dari sebanyak 4.273 masyarakat Gunung Kidul terjaring operasi yustisi akibat tidak mengenakan masker.

Dari berbagai persoalan yang menghambat penanganan pandemi tersebut, bisa dikatakan persoalannya adalah kurang satu padunya (bersatu) dalam visi dan harapan

\footnotetext{
${ }^{4}$ Leo Agustino, Analisis Kebijakan Penanganan Wabah Covid-19: Pengalaman Indonesia, Jurnal Borneo Administrator, Vol. 16 No. 2, Agustus 2020, hlm 260-264

${ }^{5}$ BPS, Perilaku Masyarakat Ditengah Pandemi Covid-19 tanggal 7-14 September 2020, BPS RI, 2020, hlm 10-11.

6 https://nasional.sindonews.com/read/255256/13/kabareskrim-sebut-demo-dan-kepulangan-habib-rizieqpenyebab-kasus-covid-19-naik-1606986739, diakses pada 25 Desember 2020.
} 
antara pemerintah dengan masyarakat, hal ini ditandai dengan adanya diskomunikasi berbagai pemangku kebijakan serta acuhnya masyarakat terhadap himbauan pemerintah. Untuk itu, kata kunci "persatuan" menjadi penting untuk ditanamkan dalam benak seluruh masyarakat Indonesia agar bisa keluar dari jeratan pandemik yang mematikan.

Banyak contoh dengan kata kunci "persatuan" yang menjadi salah satu sila dalam pancasila mampu menjadi spenyemangat dan motivasi dalam menyelesaikan berbagai persoalan, misalnya dari masalah terbebasnya dari penjajahan sampai masa kemerdekaan. Soekarno dalam Bung Karno Penyambung Lidah Rakyat mengatakan masyarakat Indonesia tidak kunjung lebih baik dan selalu terjajah akibat rakyat tidak bersatu. Alimin dalam buku yang sama juga mengatakan rakyat tidak kunjung lebih baik nasibnya saat dijajah karena rakyatnya berjuang sendiri sendiri ${ }^{7}$. Selain itu munculnya organisasi Boedi Oetomo dan Sumpah Pemuda juga merupakan cerminan persatuan anak bangsa sebagai embrio dari persatuan melawan penjajah.

Dalam konteks penanganan pandemik, temuan COED ada beberapanegara yang dianggap sukses menangani covid-19, diantaranya Australia, Austria, Jerman, dan Denmark $^{8}$. Data lain, dikutip dari Time.com edisi 16 Juni 2020, Negara Taiwan mendapat pujian karena sukses menangani covid-19 karena sedikitnya kasus dan dampak meninggal juga cukup sedikit yakni 443 positif dan meninggal 7 jiwa. Langkah yang dilakukan diantaranya dengan manajemen penanganan yang baik dari pengalaman virus SARS, pencegahan yang agresif dan dipatuhinya aturan dalam karantina9. Hal tersebut menunjukkan dengan dipatuhinya aturan mencerminkan semangat bersatu padu antara pemerintah dan msayarakat dalam mengatasi pandemic. Selain itu, dikutip dari medicalfuturis.com, Jerman sebagai salah satu Negara terbaik dalam menangani covid 19 menekankan tindakan bersama dan bersatu tangani covid19, seperti yang diungkapkan oleh Konselor Angela Merkel:"This is serious," she said in her speech. "Since German unification - no, since the Second World War - no challenge to our nation has ever demanded such a degree of common and united action" 10 . Baiq Wardani, mengungkapkan Selandia Baru sukses dalam menangani covid 19 dari 1500 kasus positif dan meninggal 20 orang, langkah yang dilakukan diantaranya karena Selandia baru mampu

\footnotetext{
${ }^{7}$ Cindy Adams, Bung Karno Penyambung Lidah Rakyat Indonesia, Terj: Syamsu Hadi-Edisi Revisi, Yogyakarta: Media Pressindo dan Yayasan Bung Karno, 2014, hlm 49.

8 The Economist Intelligence Unit Limited, The EIU tracker ranks the quality of policy responses to the pandemic given countries' risk profiles: Assessing the quality of OECD countries' responses to Covid-19, 2020.

${ }^{9}$ https://time.com/5851633/best-global-responses-covid-19/, diakses tanggal 4 Januari 2021.

10 https://medicalfuturist.com/how-germany-leveraged-digital-health-to-combat-covid-19/, diakses 4 Januari 2021
} 
mengesampingkan perbedaan pendapat dengan rasa kesadaran pentingnya persatuan dan kebersamaan hadapi covid-19, seperti yang diungkapkan oleh Direktur Jendral Kesehatan Selandia Baru, Ashley Bloomfield ${ }^{11}$. PM Selandia Baru Adern dalam kepemimpinannya, langkah yang diambil salah satunya adalah mendesak wargnya bersatu melawan covid19 ${ }^{12}$. Hal ini jika dibandingkan dengan data di Indonesia pada bulan yang sama (Juni), dikutip dari kompas.com, pada Bulan tersebut Indonesia mengalami tingkat kematian tertinggi se Asia Tenggara, dari jumlah 41.431 positif, meninggal 2.276 jiwa.

Melihat data data tersebut memang sangat mencengangkan, pasalnya dengan modal dasar Sila "Persatuan Indonesia" sebagai salah satu sila yang menjadi dasar Negara dan sering “dipasarkan” oleh MPR pada tiap kali reses, namun nampaknya nilai nilai persatuan tersebut belum tertanam kuat dalam sanubari masyarakat Indonesia, khususnya dalam menangani persoalan pandemi. Presiden Jokowi dalam Sidang Majelis PBB ke 75 juga menekankan pentingnya persatuan di tengah pandemik antar seluruh bangsa. Pada kesempatan lain, lagi lagi Jokowi menekankan pentingnya kebersamaan dan persatuan hadapi pandemik. "Mari kita terus bergandengan tangan tangani pandemi ini, dengan gotong royong, bersatu padu, karena dengan cara bersama sama kita akan dapat mengatasinya, kita tidak sendirian, kita bersama dengan negara-negara lainnya yang juga mengalami," ucap Jokowi dikutip dari detik.com. Dalam peringatan Sumpah Pemuda 2020, Jokowi juga kembali menyampaikan pentingnya bersatu. Tidak hanya Jokowi, Gubernur Jawa Tengah yang cukup familiar namanya, Ganjar Pranowo juga mengajak warganya untuk bersatu padu hadpi covid-19. Bahkan, lebih sakral akan pentingnya kata "persatuan", Staf Khusus Dewan Pengarah BPIP Romo Benny Susetyo mengatakan Pancasila menjadi modal bagi Indonesia untuk atasi pandemik ${ }^{13}$. Namun yang menjadi pertanyaan, kata "persatuan" sering disuarakan oleh para pemimpin baik pusat maupun daerah dan begitu familiar, bahkan menjadi jargon jargon dalam hadapi pandemik, faktanya pelanggaran pelanggaran dan berbagai persoalan yang mengindikasikan tercerabutnya nilai persatuan dalam menghadapi pandemik perlu ditanamkan dalam dada kita semua, ada apa dengan semua itu?. Untuk itu, berdasarkan latar belakang tersebut, penting kiranya dengan pendekatan agama dapat menjadi solusi, khususnya melalui pendekatan nilai persatuan perspektif surah Al-Imron ayat 103 sebagai upaya dalam menghadapi pandemic covid-19.

\footnotetext{
${ }^{11}$ Baiq Wardani, The Kiwi Way: Strategi Eliminasi COVID-19 Selandia Baru, Global Startegis Th.4 No 2, hlm 301 .

12 Ibid..., hlm 304.

${ }^{13}$ https://republika.co.id/berita/qbh66y291/pancasila-modal-bangsa-hadapi-pandemi-covid19, diakses tanggal 2 Januari 2021.
} 


\section{B. Metode Penelitian}

Metode penelitian yang penulis gunakan dengan metode library reseach (penelitian pustaka). Sumber data primer dalam penelitian ini yakni Alqur'an surah Al-Imran:103, Tafsir Ibnu Kasir, Tafsir Al Misbah, dan Tafsir Al-Qurtubi. Sementara data skunder yakni buku buku, artikel, jurnal, berita berita internet yang relefan dengan topik penelitian.

Penulis mengumpulkan data data dari ketiga kitab tafsir, dan jurnal maupun artikel/berita di media, kemudian menginterpretasikan menggunakan analisis deskrisi analisis, yakni dengan cara mengumpulkan data sesuai dengan topic secara konsisten dan sistematis, kemudian dianalisis, diseleksi dan digabungkan untuk mendapatkan kesimpulan dengan metode deduktif induktif (permasalahan dari umum ke khusus).

\section{Hasil dan Pembahasan}

\section{Persatuan dalam perspektif surah Al-Imran ayat $\mathbf{1 0 3}$}

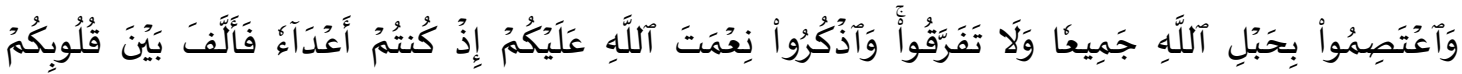

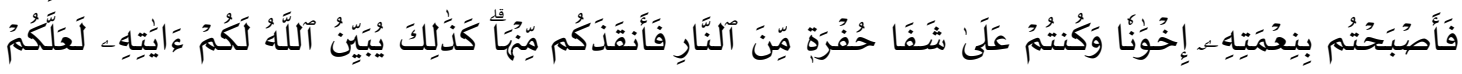

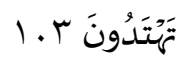

"Dan berpegang teguhlah kamu semua kepada tali (agama) Allah, dan jangnlah kamu bersecari berai. Dan ingatlah akan nikmat Allah kepadamu ketika kamu dulu (masa jahiliyah) bermusuh musuhan, maka Allah mempersatukan hatimu, lalu menjadilah kamu karena nikmat Allah, orang orang yang bersaudara, dan kamu telah berada di tepi jurang neraka, kemudian Allh menyelamtkan kamu dari padanya. Demikianlah Allah menerangkan ayat ayat Nya kepadamu agar kamu mendapat petunjuk."

\section{a. Tafsir Ibnu Katsir}

Firman Allah Swt.:

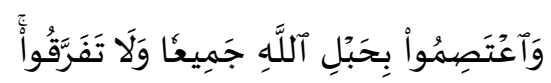

"Dan berpeganglah kamu semuanya kepada tali (agama)Allah, dan janganlah kalian bercerai-berai”.(Ali Imran: 103).

Menurut suatu pendapat, yang dimaksud dengan hablillah ialah janji Allah. Seperti yang disebutkan di dalam ayat selanjutnya, yaitu:

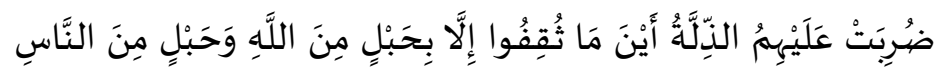

"Mereka diliputi kehinaan di mana saja mereka berada, kecuali jika mereka berpegang kepada tali (agama) Allah dan tali (perjanjian) dengan manusia”. (AlImran: 112) 
Pendapat lain, yang dimaksud adalah Al-Qur'an, seperti yang disebutkan dalam hadis Al-Haris Al-A'war, dari sahabat Ali secara marfu' tentang sifat AlQur'an yaitu:

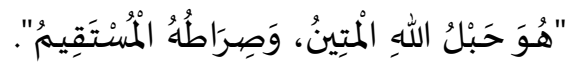

"Al-Qur'an ialah tali Allah yang kuat dan jalan-Nya yang lurus".

Sehubungan dengan hal tersebut, terdapat hadis yang khusus membahas tentang makna tali Allah:

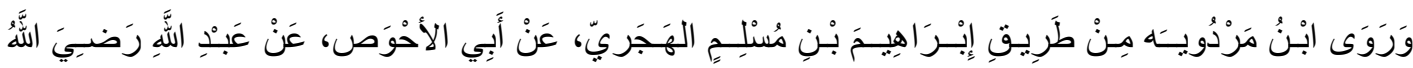

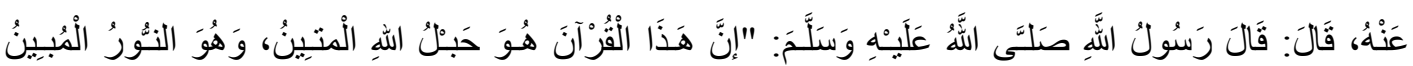

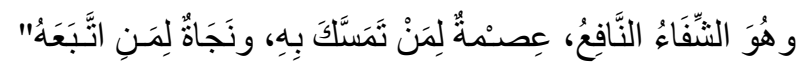

"Ibnu Murdawaih meriwayatkan dari jalur Ibrahim Ibnu Muslim Al Hijri, dari Abu Ahwas, dari Abdullah ra yang menceritakan bahwa Rasulullah saw pernah bersabda: sesungguhnya Al Quran ini ialah tali Allah yang kuat. Ia ialah cahaya yang jelas, ia ialah penawar bermanfaat, perlindungan bagi orang yang berpegang kepadanya dan keselamatan bagi orang yang mengikuti (petunjuk) Nya"14

Firman Nya:

$$
\text { وَلا تَفَرَّقُوا }
$$

“Dan janganlah kalian bercerai berai”. (Ali-Imran ayat 103)

Allah memerintah mereka agar bersama jamaah (kesatuan) serta melarang cerai berai. Terdapat banyak hadist yang berbicara persoalan larangan cerai berai dan menekankan untuk bersatu. Misal Rasulullah saw bersabda:

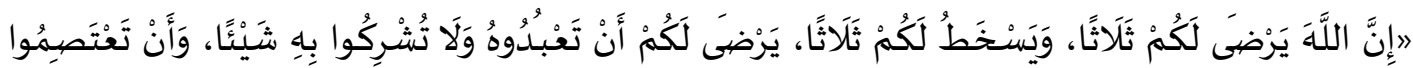

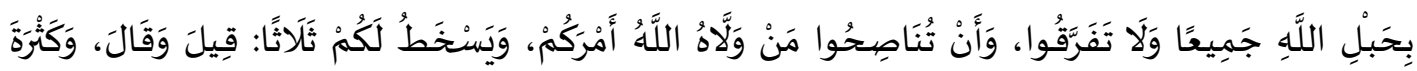

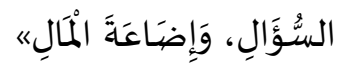

"Sesungguhnya Allah rida kepada kalian dalam tiga perkara dan murka kepada kalian dalam tiga perkara. Allah rida kepada kalian bila kalian menyembah-Nya dan kalian tidak mempersekutukan-Nya dengan sesuatu pun, bila kamu sekalian berpegang teguh kepada tali Allah dan tidak bercerai berai, dan bila kalian saling menasihati dengan orang yang dikuasakan oleh Allah untuk mengurus perkara kalian.Dan Allah murka kepada kalian dalam tiga perkara, yaitu qil

${ }^{14}$ Al Imam Abu Fida Isma'il Ibnu Kasir Ad Dimasyqi, Tafsir Ibnu Kasir, Juz 4, Surah Al Imran 92 s.d An Nisa 23, Sinar Baru Algesindo, hlm 48-50 
dan qal ( banyak bicara atau berdebat ), banyak bertanya dan menyianyiakan (meng hambur-hamburkan) harta" "15.

Bila persatuan dan kesatuan ada dalam hidup mereka, mereka akan selamat dari kesalahan, seperti dalam banyak hadist tentang persatuan dan kesatuan. Sangat dikhawatirkan jika mereka bertentangan dan tercerai berai dan masalah ini ternyata menimpa umat, hingga mereka terpecah jadi 73 golongan. Dan ada 1 golongan yang selamat masuk syurga serta diselamatkan dari neraka. Mereka ialah orang orang yang mengikuti langkah Rasulullah saw dan para sahabatnya ${ }^{16}$.

\section{b. Menurut tafsir Al Misbah surah Al-Imran:103}

Dalam tafsir Al Misbah ,bahwa pesan yang lalu ditujukan untuk tiap perorangan/pribadi, sedangkan pesan sejenis dalam surat Al Imran:103, dimaksudkan untuk kaum muslimin secara umum, seperti pada kata “jami'an/semua" dan firman-Nya: "wala tafarraqu/ janganlah bercerai berai".

Pesan:"berpegang'teguhlah", yaitu usaha yang kuat dengan penuh tenaga untuk mengaitkan diri satu dengan lainnnya berdasarkan ajaran Allah secara disiplin tanpa kecuali. Hingga jika ada yang kelupaan diingatkan, jika ada yang terpeleset bantu berdiri agar berpegang pada tali agama Allah swt. Jika kamu lengah atau salah, orang yang menyimpang maka keseimbangan akan kacau, dan disiplin akan rusak, untuk itu bersatu padu dan jangan bercerai berai serta ingat ni'mat Allah kepadamu ${ }^{17}$.

Bandingkan keadaanmu saat datang agam Islam dengan masa Jahiliah yang bermusuhan, dengan tanda begitu lamanya peperangan dari generasi ke generasi, maka Allah mempersatukan hatimu pada satu jalan dan arah yang sama, lalu menjadilah kamu, karena nikmat Allah yaitu dengan Islam, orang orang yang bersaudara; hingga sekarang tidak ada bekas luka di hatimu sekalian. Penyebutan nikmat ini ialah argument untuk keharusan memelihara persatuan dan kesatuan, sebuah argumentasi atas dasar pengalaman mereka. Itu merupakan nikmat dunia yang didapat dan kamu alami, di akhirat kelak akan mendapatkan nikmat juga, karena jika kamu bermusuhan, sesungghnya kamu telah ada di tepi jurang

\footnotetext{
${ }^{15}$ Al Imam Abu Fida Isma’il Ibnu Kasir Ad Dimasyqi, Tafsir Ibnu Kasir..., hlm 50.

${ }^{16}$ Al Imam Abu Fida Isma'il Ibnu Kasir Ad Dimasyqi, Tafsir Ibnu Kasir..., hlm 50-51

${ }^{17}$ M. Quraish Shihab, Tafsir Al Misbah: Pesan, Kesan dan Keserasian Al Qur'an, Cet IV, Tangerang: Lentera Hati, 2005, hlm 169-170
} 
neraka, karena, kamu hidup tidak ada bimbingan wahyu, kemudian dengan datangnya Islam, Allah menyelamatkan kamu dari api neraka ${ }^{18}$.

Kata i'tashimu diambil dari kata ashama, yang mempunyai makna menghalangi. Potongan ayat tersebut mempunyai makna perintah agar berpegang pada tali Allah yang berfungsi untuk menghalangi seseorang terjatuh. Kata habl yang berarti tali, ialah apa yang dipakai untuk mengikat sesuatu untuk mengangkat ke atas atau menurunkan ke bawah agar sesuatu tersebut tidak terlepas atau terjatuh. Memang seperti ditulis Fakhruddin ar-Razi, tiap orang yang berjalan di jalan yang susah, khawatir terpeleset jatuh, tapi bila ia berpegang tali yang terulur pada kedua ujung jalan yang dilewatinya, maka ia akan mempunyai rasa aman untuk tidak terjatuh, apalagi bilaa tali itu kuat dan memegangnya pun kuat. Yang memilih tali rapuh, atau tidak berpegang teguh/kuat walaupun talinya kuat, sangat mungkin akan terpeleset seperti dialami oleh banyak orang. Yangdimaksud tali dalam ayat ini ialah ajaran agama, atau al-Qur'an. Nabi Muhammad saw menggambarkan alQur'an dengan sabdanya: "huwa habl Allah al-matm/ Dia adalah tali Allah yang kokoh"19.

Firman Allah: "fa'allafa baina qulubikum", yaitu mengharmoniskan atau mempersatukan hatimu, menunjukkan begitu kuat ikatan kasih sayang dan persatuan mereka, karena bukan hanya langkah mereka tetapi hati nya yang diharmoniskan oleh Allah swt. Apabila hati telah menyatu, maka segalanya dipikul menjadi ringan dan missal kesalah pahaman muncul, maka akan gampang diselesaikan. Memang, yang terpenting ialah kesatuan hatinya umat, lain kesatuan organisasi atau kegiatan ${ }^{20}$.

Kata "ikhwnan" ialah bentuk jamak dari kata akh yang lazim diartikan saudara, makna asalnya adalah sama. Oleh nya itu, al Qur an menyebut orangorang yang boros ikhwan asysyayathin (Surah al-Isra' [17]: 27) dalam arti memiliki sifat sama dengan sifat setan. Mereka yang dipersatukan hatinya oleh Allah akan merasa dirinya sama dengan lainnya. Yang ringan dan berat sama dijinjing dan dipikul. Bila saudaranya sakit mereka rasakan bersaama dan menikmati kegembiraan bersama ${ }^{21}$.

\footnotetext{
${ }^{18}$ M. Quraish Shihab, Tafsir Al Misbah: Pesan, Kesan dan Keserasian Al Qur'an, Cet IV, Tangerang: Lentera Hati, 2005, hlm 169-170

${ }^{19}$ M. Quraish Shihab, Tafsir Al Misbah..., hlm 171

${ }^{20}$ M. Quraish Shihab, Tafsir Al Misbah..., hlm 172

${ }^{21}$ M. Quraish Shihab, Tafsir Al Misbah..., hlm 172.
} 


\section{c. Tafsir Al-Qurthubi}

Pada surah Al-Imran: 103 ada dua persoalan: (1) kata wa'tashimu mempunyai makna mencegah, yakni dengan menyuruh orang untuk menjaganya dari berbagai hal yang dapat menyakiti.sedang kata hablu ialah kata musytarak yang mempunyai banyak makna/arti. Dari aspek bahasa arti asalnya ialah: penyebab yang bisa mengantarkan pada keinginan dan kebutuhan (2) Firman Allah, "janganlah kamu bercerai-berai”, maksudnya ialah agama kalian, seperti kaum Yahudi dan Nasrani yang bercerai berai dalam agama mereka. Dari Ibnu Maseeud dan yang lain bahwa artinya bisa juga: janganlah kalian bercerai berai dengan mengikuti hawa nafsu dan tujuan-tujuan yang beraneka ragam. Jadilah kalian saudara satu sama lainnya didalam agama Allah. Maka, bila telah bersatu akan jadi penghalang bagi mereka untuk memisahkan diri dan saling membelakangi ${ }^{22}$.

Hal tersebut ditandai dengan potongan ayat setelahnya, yaitu: "dan ingatlah akan nikmat Allah kepadamu ketik kamu dahulu (masa Jahiliah) bermusuh musuhan, maka Allah mempersatukan hatimu, lalu menjadilah kamu karena nikmat Allah orang-orang yang bersaudara." Pada ayat tersebut tidak ada dalil mengenai haramnya berbeda pendapat pada masalah cabang-cabang ajaran agama. Olehnya itu bukan sebuah perselisihan ${ }^{23}$.

Namun yang dimaksud dengan perselisihan ialah yang tidak bisa disatukan dan dihimpun mejadi satu. Adapun hukum tentang masalah ijtihad, perbedaan pendapat yang ada di dalamnya ialah karena diluar masalah hukum-hukum yang wajib/fardhu dan merupakan pesoalan yang mendetail mengenai syariat. Para sahabat masih berbeda pendapat tentang hukum-hukum banyak peristiwa, tetapi mereka tetap bersatu ${ }^{24}$. Lanjutnya, Al-Qurthubi dalam penafsiran ayat tersebut mengutip perkataan Ibnu Abbas kepada Sammak Al-Hanafi :'Wahai Hanafi, Jamaah-jamaah, sesungguhnya binasa binasa umat saat ini karena mereka terpecah belah", "Dan berpeganglah kamu semuanya kepada tali (agama) Allah, dan janganlah kamu bercerai berai" ${ }^{25}$.

Allah mewajibkan kepada umat manusia untuk berpegang teguh pada Kitab Nya, sunnah Rasul-Nya, serta kembali kepada mereka saat ada perselisihan. Allah

\footnotetext{
${ }^{22}$ Tafsir Alqurthubi jilid 4, Surah Al Imran ayat 103, hlm 398.

${ }^{23}$ Tafsir Alqurthubi..., hlm 400.

${ }^{24}$ Tafsir Al Qurthubi..., hlm 400

${ }^{25}$ Tafsir Al Qurthubi..., hlm 409.
} 
memberi perintah kepada kita untuk bersatu dan berpegang teguh pada ajaran $\mathrm{Al}$ Qur'an dan hadis, baik dengan keyakinan maupun perbuatan. Ini merupakan syarat tercapainya kesepakatan dan keteraturan sesuatu yang tercerai-berai, dengan $\mathrm{Al}$ Quran dan Sunnah Nabi akan tercapai kemaslahatan dunia akhirat, serta keselamatan dari bercerai berai. Allah memberi perintah pada kita agar bersatu dan melarang bercerai berai seperti yang terjadi pada ahlul kitab (Yahudi dan Nasrani). Inilah makna dari ayat tersebut secara sempurna ${ }^{26}$.

\section{Urgensi Persatuan Dalam Surah Al Imran 103 Untuk Atasi Covid 19}

Dalam tafsir Ibnu kasir, dinyatakan bahwa umat manusia disuruh berpegang teguh pada tali Allah dan dilarang bertikai/bercerai berai, apabila mereka keluar dari itu maka berada dalam kehinaan. Hal tersebut dipertegas lagi dengan hadis Nabi saw yang menyuruh umatnya berpegang teguh kepada Alqur'an karena menjadi penawar, perlindungan dan keselamatan bagi orang yang mengikutinya.

Dalam tafsir Al Misbah, umat manusia khususnya kaum muslimin juga dituntut untuk berpegang teguh pada tali Allah secara bersama sama antara satu dengan lainnya untuk saling mengingatkan apabila ada yang lupa dan apabila ada yang tergelincir saling mengarahkan. Pada kata fa allafa baina qulubikum, menunjukkan pentingnya harmonisasi hati atau mempersatukan hati. Hal ini menandakan dengan persatuan pertalian kasih sayang dan persatuan mereka jadi kuat. Sebab, yang diharmoniskan Allah bukan tindakannya namun hati yang menggerakkan segala sesuatu menjadi ringan dipikul dan seandainya kesalahpahaman muncul, maka akan mudah diselesaikan. Tafsir tersebut menunjukkan betapa pentingnya persatuan itu bukan atas nama golongan atau organisasi, melainkan hati dari setiap individu yang harus dipelihara karena kalau bermusuh musuhan akan mendekatkan manusia pada tepi neraka.

Dalam tafsir Al Qurtbi, dapat disimpulkan bahwa makna dalam al Imron 103 secara sempurna bahwa Allah menyuruh untuk bersatu dalam berpegang teguh terhadap ajaran Al Qur an dan hadis, baik melalui keyakinan maupun perbuatan. Hal tersebut adalah syarat terwujudnya kesepakatan dan sesuatu yang tercerai akan menjadi teratur/disatukan, dengan Alquran dan Hadis akan tercapai kebaikan baik dunia dan akhirat serta keselamatan dari perselisihan/perpecahan.

\footnotetext{
${ }^{26}$ Tafsir Al Qurthubi,hlm 409-410.
} 
Melihat dari ketiga tafsir tersebut diatas, dapat disimpulkan bahwa persatuan dan dilarang bercerai berai merupakan ajaran agama yang harus dilakukan, apabila terjadi bercerai berai, segeralah kembali kepada tali (agama) Allah. Bahkan menurut alQurtubi, dengan bercerai berai akan mengantarkan pada kebinasaan.

Pentingnya kata "persatuan" dalam tafsir tersebut di atas nampak jelas sebagai ajaran agama yang harus dilakukan walaupun dalam kondisi atau konteks kehidupan yang berbeda beda. Banyak cerminan/contoh kata kata sakral tersebut sering digaunggaungkan untuk mengajak seseorang dalam mengatasi suatu permasalahan yang melibatkan khalayak/kelompok. Misalnya saja yang mengiringi dan menjadi semangat lahirnya organisasi Boedi Oetomo, Sumpah Pemuda, bahkan Soekarno dalam menyemangati rakyatnya baik melalui tulisan maupun pidato pidaonya menekankan tentang "persatuan". Tidak hanya itu, cita cita Negara yang bersatu juga termaktub dalam pembukaan UUD 1945, bahkan pilar persatuan menjadi sila ke 3 dalam pancasila. Hal ini menunjukkan betapa pentingnya kata "persatuan" tersebut. Bahkan kata persatuan tersebut menjadi ajaran yang penting bagi umat manusia khhususnya Islam, seperti yang ada dalam firman Allah surah Al-Imran:103, yang menunjukkan kata perintah seperti penjelasan tafsir di atas, artinya umat manusia khususnya Islam diperintahkan oleh Allah untuk bersatu dan dilarang bercerai berai, yang apabila dilanggar tentu akan ada konsekuensinya, seperti ada di tepi jurang neraka.

Jika ayat tersebut ditafsirkan dengan konteks saat ini yakni persoalan pandemik Corona Virus Deserse (Covid-19) yang "memporak porandakan" tatanan kehidupan, nampaknya kata dan semangat persatuan sangat relevan untuk ditanamkan dalam setiap sanubari. Persatuan tidak hanya dilihat sebagai jargon semata seperti "bersatu lawan covid-19", melainkan mengandung nilai sekaligus ajaran yang harus diimplementasikan, bahkan dalam tafsir menunjukkan perintah untuk bersatu.

Jauh sebelum masalah covid-19, bahkan sebelum Indonesia merdeka, ajakan bersatu dan semangat dari persatuan itu sudah menjadi semangat yang diajrakan oleh para founding father kita. Soekarno mengingatkan betapa pentingnya persatuan yang bisa mengantarkan terbebasnya Indonesia dari penjajah ${ }^{27}$. Tidak hanya itu, naskah deklarasi dalam sumpah pemuda juga mengandung makna dan ajakan bersatu dalam bahasa, tanah air dan berbangsa. Dengan semangat tersebut sehingga memunculkan semangat kebangkitan para pemuda yang membuat "gelisah" Belanda yang sedang

${ }^{27}$ Lihat Cindy Adams, Soekarno Penyambung Lidah Rakyat Indonesia. 
menjajah Indonesia ${ }^{28}$. Hadratus Syekh Hasyim Asy'ari tokoh pendiri organisasi social keagamaan terbesar di Indonesia juga telah menyampaikan betapa pentingnya persatuan. Persataun yang dimaksud dalam pemikiran KH. Hasyim Asy'ari tentang persatuan, menurut Muhammad Coirun Nizar terbagi dua, yakni: pertama, persatuan dalam konteks kebangsaan, bahwa persatuan itu dilandasi persamaan bangsa. kedua, persatuan keagamaan yang dilandasi kesamaan agama ${ }^{29}$.

Belajar dari sejarah akan pentingnya persatuan yang tidak hanya berupa ajaran, namun juga mengandung nilai nilai filosofis, menjadi penting hal itu ditanamkan kembali saat menghadapi berbagai persoalan bangsa. Seperti halnya nilai filosofis dalam dasar Negara sila persatuan Indonesia misalnya menurut Sunarni Yassa, salah satunya adalah mengandung makna menumbuhkan rasa senasib dan sepenanggungan ${ }^{30}$. Dalam konteks ini, tentunya seluruh elemen bangsa hendaknya bersatu padu bersama sama mengatasi pandemik covid-19 atas dasar senasib dan sepenanggungan yang setiap saat, setiap waktu, tidak mengenal pangkat dan golongan virus tersebut bisa mengenai seseorang tanpa pandang bulu. Untuk itulah penting memaknai persatuan dalam mengatasi covid-19 bukan soal siapa yang kuat dan siapa lemah, melainkan bersama senasib sepenanggungan dalam bingkai NKRI.

Lebih jauh, dalam ajaran Islam jelas ditekankan seperti dalam surah Al-Imran: 103, persatuan itu menjadi ajaran yang harus dilaksanakan dan bercerai berai itu dilarang karena dapat menimbulkan perpecahan dan mendekatkan diri pada api neraka. Memang konteks ayat tersebut turun bukan pada kondisi pandemik seperti saat ini, namun ayat tersebut juga tidak menjastifikasi pada satu persoalan tertentu, artinya persatuan sangat diperlukan guna menghadapi persoalan dan waktu yang berbeda seperti pandemik. Contoh sudah jelas menggambarkan, dengan adanya orang orang yang acuh (bercerai berai) dalam pandemik, akhirnya kasus positif meningkat. Pentingnya persatuan bukan hanya sebagai semangat, melainkan bernilai ibadah, hal ini juga diperkuat dengan hadis Nabi saw yang artinya:

"Telah menceritakan kepadaku Zuhair bin Harb telah menceritakan kepada kami Jarir dari Suhail dari ayahnya dari Abu Hurairah dia berkata, Rasulullah shallallahu 'alaihi wasallam bersabda: Sesungguhnya Allah menyukai bagimu tiga perkara dan membenci tiga perkara; Dia menyukai kalian supaya beribadah

${ }^{28}$ Sutejo K. Widodo, Memaknai Sumpah Pemuda di Era Reformasi, Humanika, Vol. 16, No. 9, Desember 2012,hlm 4

${ }^{29}$ Muhammad Coirun Nizar, Pemikiran KH. Hasyim Asy'ari tentang Persatuan, Endogami: Jurnal Ilmiah Kajian Antropologi, Vol. 1, No. 1, Desember 2017, hlm 66

${ }^{30}$ Sunarni Yassa, Jurnal Citizenship: Media Publikasi Pendidikan Pancasila dan Kewarganegaraan, Vol. 1, No. 1 Tahun 2018, hlm 5. 
kepada-Nya dan tidak menyekutukan-Nya dengan sesuatu apapun, kalian berpegang teguh dengan agama-Nya dan tidak berpecah belah. Dan Allah membenci kalian dari mengatakan sesuatu yang tidak jelas sumbernya, banyak bertanya dan menyia-nyiakan harta. Dan telah menceritakan kepada kami Syaiban bin Farruh telah mengabarkan kepada kami Abu Awanah dari Suhail dengan isnad seperti ini, namun dia berkata, 'Dan dia murka terhadap tiga perkara dari kalian, dan tidak menyebutkan, dan janganlah kalian berpecah belah" ${ }^{31}$.

Dalam hadis tersebut, mengandung makna konsekuensi dari berpegang teguh pad agama Allah dan tidak tercerai berai" (bersatu) merupakan hal yang diridhai Allah. Artinya ketika umat manusia mempunyai semangat yang sama untuk bersatu padu hadapi covid-19, maka hal itu akan diridhai Allah. Tentunya, bagi Indonesia yang notabenenya mayoritas muslim sangat ditekankan apabila "persatuan" diimplementasikan dengan baik, bukan saja soal dampak positive dari menyelesaikan pandemik dengan semangat bersatu seperti Taiwan, Jerman dan Selandia Baru yang notabenenya minoritas muslim, tapi akan bernilai ibadah dan mendapat ridha Allah swt karena mengamalkan persatuan dan tidak bercerai berai dalam hal penanganan musibah ini. Jika berkaca dari langkah langkah beberapa Negara yang berhasil atasi pandemic covid-19 seperti Taiwan, Jerman, dan Selandia Baru, point penting dalam penangannnya adalah bersatu padu (adanya persatuan), tidak mustahil pula bagi Indonesia untuk terbebas dari "jajahan” virus corona.

\section{Membingkai Persatuan Hadapi Covid-19}

\section{a. Membingkai Persatuan dalam konsep keimanan}

Sejak permulaan manusia, seperti diterangkan dalam surah Al Qur'an, manusia dulu awalnya ialah umat satu, seperti dalam Qs. Al-Baqarah yang artinya:

"Manusia itu adalah umat yang satu. (setelah timbul perselisihan), maka Allah mengutus para nabi, sebagai pemberi peringatan, dan Allah menurunkan bersama mereka Kitab yang benar, untuk memberi keputusan di antara manusia tentang perkara yang mereka perselisihkan. Tidaklah berselisih tentang Kitab itu melainkan orang yang telah didatangkan kepada mereka Kitab, yaitu setelah datang kepada mereka keterangan-keterangan yang nyata, karena dengki antara mereka sendiri. Maka Allah memberi petunjuk orang-orang yang beriman kepada kebenaran

\footnotetext{
${ }^{31}$ Hadis Sahih Muslim No 3632.
} 
tentang hal yang mereka perselisihkann itu dengan kehendak-Nya. Dan Allah selalu memberi petunjuk orang yang dikehendaki-Nya kepada jalan yang lurus" ${ }^{22}$.

Dalam tafsir Ibnu Kasir, dijelaskan Ibnu Jarir meriwayatkan dari Ibnu Abbas: "Antara Nuh dan Adam itu berbeda sepuluh generasi, umatnya berteguh pada syari'at Allah. Lalu terjadi selisih diantara mereka, kemudian Allah mengutus Nabi yang menyampaikan kabar gembira dan memberi peringatan. Ibnu Kasir berpendapat bahwa pendapat yang sumbernya dari Ibnu Abbas mempunyai sanad dan makna yang lebih shahih. Karena umat saat itu menganut agama yang dibawa Adam hingga akhimya mereka menyembah berhala, kemudian Allah swt mengutus Nabi Nuh pada umat tersebut. Nabi Nuh ialah rasul pertama yang diutus ke muka bumi. $^{33}$

Berdasarkan ayat tersebut, seperti pada permulaan manusia adalah umat yang satu, dan akhirnya berselisih kemudian diberi petunjuk oleh Nabi, maka setidaknya manusia saat ini juga perlu merenungi kembali siapa jatidiri sebenarnya saat permulaan manusia sehingga ego, bercerai berai, perselisihan dapat dihindari, dan apabila itu terjadi maka kembali kepada tali agama Allah.

Implementasi persatuan tidak hanya sesama muslim saja, melainkan kepada non muslim karena pada dasarnya Allah swt menciptakan perbedaan, tujuannya agar saling mengenal seperti dalam firman Allah berikut, yang artinya:

Artinya:"Hai manusia, sesungguhnya Kami menciptakan kamu dari seorang lakilaki dan seorang perempuan dan menjadikan kamu berbangsa-bangsa dan bersukusuku supaya kamu saling mengenal. Sesungguhnya orang yang paling mulia di antara kamu di sisi Allah ialah orang yang paling bertakwa di antara kamu. Sesungguhnya Allah Maha Mengetahui lagi Maha Mengenal"34.

Dari ayat tersebut, penekanan perbedaan diciptakan agar saling mengenal, bukan perpecahan/cerai berai, lalu yang dinilai kemuliaannya oleh Allah adalah berdasarkan ketaqwaan, bukan golongan, suku, maupun warna kulit. Untuk itu, konteks ayat ini diterapkan dalam keseharian sangat relevan dengan keberagaman yang ada di Indonesia agar saling mengenal bukan saling menonjolkan golongan, kelompok atau warna kulit, terlebih lagi disaat pandemik saat ini, kebersamaan dan

\footnotetext{
${ }^{32}$ Surah Al-Baqarah ayat 103

${ }^{33}$ Tafsir Ibnu Kasir Jilid 1, Surah Albaqarah ayat 213, hlm 409-410.

${ }^{34}$ Qs. Al-Hujara:13
} 
persatuanlah yang dibutuhkan untuk bersama sama memahami satu sama lain, senasib sepenanggungan agar terhindar dari covid-19.

Berdasarkan beberapa redaksi ayat pentingnya bersatu padu, dilarang bercerai berai, dan perbedaan ada agar saling mengenal karena yang dinilai Allah adalah ketaqwaan seseorang, maka penting kiranya menyemangati umat manusia agar bersatu dalam menghadapi covid 19 melalui pendekatan keimanan.

Tidak hanya itu, perintah untuk bersatu padu dan dilarang bercerai berai seperti dalam ketiga tafsir dalam surah Al Imron ayat 103 yang penulis sebutkan di atas, menyiratkan bahawa dengan perintah terhadap persatuan tersebut itu akan menghindarkan dari tepi neraka. Bahkan kalau ada bercerai berai antara satu dengan lainnya akan mendekatkan kepada tepi neraka dan kehancuran pun terjadi, seperti dikisahkan bercerai berainya pada masa jahiliyah.

\section{b. Membingkai persatuan dalam aras ketaatan}

Dalam kehidupan bernegara, Islam mengajarkan harus ada pemimpin, dan umat manusia dituntut untuk taat pada pemimpinnya dalam hal kebaikan/tidak maksiat. Seperti dalam Qs An Nisa: 59:

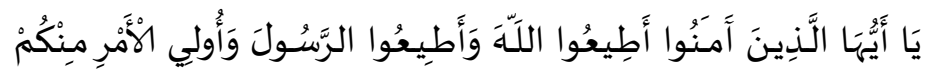

"Hai orang orang yang beriman, taatilah Allah dan taatilah Rosul (Nya) dan Ulil Amri diantara kamu"

Hadis Nabi dalam Sahih Buhari juga mengisyaratkan untuk mentaati pemimpin, yang artinya:

"...Rasulullah shallallahu 'alaihi wasallam menarik Al Asy'ats bin Qois dan bersabda: Dengarlah dan taatlah kamu sekalian (pada mereka), maka sesungguhnya di atas mereka ada tanggung jawab/kewajiban atas mereka sendiri dan bagimu ada tanggung jawab tersendiri." (HR Muslim) $)^{35}$.

Berdasarkan dalil dalil tersebut, umat manusia, khsusunya Islam dituntut untuk taat pada pemimpin. Ketaatan terhadap pemimpin tidak melihat latar belakang pemimpin tersebut, apapun suku, ras, agama, warna kulit, yang dilihatnya adalah karakter dan muatan makna yang ditaati, yakni tidak menyuruh kepada kemaksiatan. Hal itu, berkaitan dengan penangan covid-19, bahwa pemimpin menyuruh rakyatnya untuk mematuhi protocol kesehatan serta aturan aturan lain,

${ }^{35}$ Hadis Riwayat Muslim No 3433 
maka hal itu sudah selayaknya untuk dipatuhi. Perintah itu jelas untuk kebaikan, bukan kemaksiatan, bahkan kebaikan tersebut bukan hanya untuk pemimpin, melainkan untuk seluruh masyarakat Indonesia.

Di Indonesia sendiri pemimpin tertinggi disebut dengan Presiden (Kepala Negara), tingkat propinsi disebut dengan Gubernur, tingkat Kabupaten/Kota disebut dengan Bupati/Walikota. Maka untuk itu, berkaitan dengan penanganan covid-19, masyarakat hendaknya taat pada pemimpin di tiap tiap daerah sebagai perpanjangan pemerintah pusat. Mislanya saja melalui protokol kesehatan, pemerintah membatasi interaksi sosial dengan physical distancing dengan cara mencuci tangan, memakai masker dan menjaga jarak itu harus dipatuhi. Hal itu perlu dilakukan bukan semata mata taat pada pemimpin, melainkan dengan ketaatan tersebut, berdasarkan kajian kajian yang telah dilakukan pemerintah, hal tersebut bisa memutus/mengurangi mata rantai penyebaran virus. Selain turut serta mencegah penyebaran covid-19, hal itu juga berniali ibadah karena yang diperintahkan pemimpin bukan hal kemaksiatan melainkan kemaslahatan bersama.

\section{c. Membingkai Persatuan dalam menangkal hoaks dan mengendalikan diri}

Banyaknya berita berita bohong/hoaks yang berseliweran di berbagai media soal pandemik turut memperkeruh penanganan covid-19. Dilansir dari okezone.com, kominfo mencatat terdapat 1028 hoaxs tentang covid hingga 8 Agustus 2020 yang tersebar di berbagai media social ${ }^{36}$. Temuan Rochani Nani Rahayu \& Sensusiyati, dalam menganalisi hoax tentang covid-19 di berbagai media, menemukan tiga topik pemberitaan yakni virus corona, pengobatan dan perilaku masyarakat ${ }^{37}$. Begitu banyaknya hoax yang beredar dan dapat diakses oleh masyarakat tentu akan menghambat penanganan pandemic itu sendiri dan merugikan banyak pihak, seperti yang diungkapkan oleh Luthfi Maulana, terdapat 5 dampak negative dari hoax; (1) Merugikan masyarakat, hoax memuat kebohongan serta fitnah, (2) Memecah belah masyarakat, (3) Memengaruhi opini publik, hoax jadi alat profokasi, (4) kesengajaan dibuatnya berita hoax untuk pojokkan salah satu

36 https://nasional.okezone.com/read/2020/08/12/337/2261100/kominfo-catat-1-028-hoaks-tersebarterkait-covid-19, diakses 5 Januari 2020

${ }^{37}$ Rochani Nani Rahayu \& Sensusiyati , Analisis Berita Hoax Covid -19 Di Media Sosial Di Indonesia, Intelektiva : Jurnal ekonomi, Sosial \& Humaniora,2020, hlm 60. 
pihak,hingga dapat menimbulkan adu domba terhadap sesama pemeluk Islam, (5) menimbulkan ketakutan masyarakat dengan berita bohong yang sengaja dibuat ${ }^{38}$.

Dalam Islam, menyebarkan berita bohong/hoax akan mendapatkan ancaman, seperti dalam surah An-Nur ayat 11:

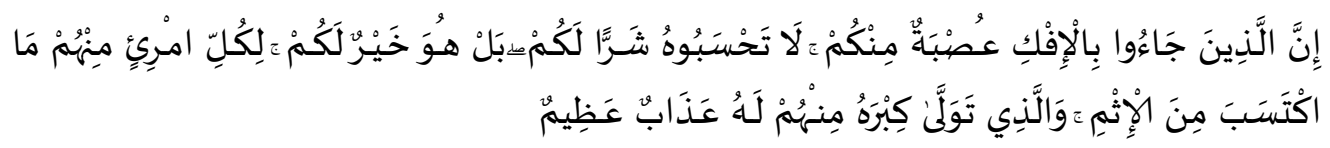

"Sesungguhnya orang-orang yang membawa berita bohong adalah golongan kamu, Janganlah kamu menganggapnya buruk bagi kamu, bahkan ia adalah baik bagi kamu, tiap-tiap orang dari mereka memperoleh apa yang dia kerjakan dari dosa itu, dan siapa yang mengambil bagian yang terbesar di dalamnya di antara mereka, bagian azab yang besar".

Dalam tafsir Al Misbah, ayat tersebut adalah kecaman, untuk orang yang menuduh Aisyah istri Nabi Muhammad saw, tanpa bukti. Lalu Allah berfirman, "Sesungguhnya orang yang membawa dan menyebarkan berita bohong secara sengaja, berita bohong itu berkaitan dengan kehormatan keluarga Nabi SAW,itu ialah golongan dari kelompokmu (hidup ditengah kaum mukmin). Janganlah kamu menganggap baik atau buruk, karena dengan demikian kamu dapat membedakan siapa yang munafik dan siapa yang kuat imannya (akan mendapatkan balasan yang sesuai)" ${ }^{\prime 39}$.

Pelajaran yang dapat diambil berdasarkan riwayat dan penjelasan ayat tersebut, pelajaran yang dapat diambil adalah sebenarnya masalah berita bohong(hoax) yang merebak di Indonesia bukan hal baru, pada masa Nabi SAW pun sudah ada berita bohong, bahkan kejadian tersebut menimpa keluarga Nabi SAW sendiri. Dari kasus tersebut, kemudian Allah swt menanggapi dengan memberi jawaban kepada umat Islam agar tidak berada dalam kerugian (memproduksi/menyebarkan berita bohong alias hoax).

Menanggapi maraknya informasi berupa kebohongan alias hoax, Islam jauh jauh hari dengan kesempurnaannya telah mengingatkan dan mengajarkan untuk berkata benar, seperti dalam surah Al Ahzab:70-71, yang artinya:

"Hai orang-orang yang beriman, bertaqwalah kamu kepada Allah dan sampaikanlah perkataan yang benar. Allah akan memperbaiki bagi amalan-amalanmu dan

38 Luhtfi Maulana, Kitab Suci Dan Hoax: Pandangan Alquran Dalam Menyikapi Berita Bohong, Wawasan: Jurnal Ilmiah Agama dan Sosial Budaya 2, 2 (Desember 2017), hlm 213

${ }^{39}$ Qurais Shihab, Tafsir Al-Misbah Pesan, Kesan dan Keserasian Al-Quran, hlm 294. 
mengampuni bagi dosa-dosamu. Dan barang siapa yang mematuhi Allah dan RasulNya maka ia akan memperoleh kemenangan yang besar”.

Selain anjuran berbicara benar, al-quran juga mengajarkan agar mengklarifikasi atau tabayyun apabila mendapat berita, seperti firman Allah dalam QS. Al-Hujurat: 6, artinya:

"Hai orang-orang yang beriman, jika datang kepadamu orang fasik membawa berita maka periksalah dengan teliti (fa tabayyanu), agar kamu tidak menimpakan suatu musibah kepada suatu kaum tanpa megetahui keadaan yang menyebabkan kaтu menyesal atas perbuatan itu”.

Surah tersebut mengandung makna bahwa ketika mendapat informasi,maka diperintahkan untuk meneliti, melakukan croschek kembali tentang kebenaran informasi yang didapatkan.

Tidak hanya berita bohong, bahkan mis informasi dan koordinasiantar stake holder juga turut menjadi pemicu ketidakpercayaan masyarakat tentang kebenaran informasi, khususnya berkaitan dengan penanganan covid-19. Untuk itu semua pihak perlu bersatu padu dalam hal distribusi dan serap informasi, jangan sampai informasi yang belum diverifikasi kebenarannya turut disebarkan yang dapat memperunyam persoalan.

Para stake holder dalam hal ini pemerintah yang bertanggungjawab dalam hal kebijakan, perlu koordinasi dan kesatuan informasi yang betul betul valid sebelum tersampaikan ke masyarakat. Begitu juga sebaliknya masyarakat perlu bersatu padu dan memberikan kepercayaan kepada pemerintah yang sah dan kompeten dalam menangani pandemi. Bersatu padu yang dimaksud adalah bersama menyebarkan kebaikan dan berpadu dalam meniadakan keburukan, salah satunya tidak turut serta menyebarkan berita berita yang kebenarannya masih dipertanyakan, yang dapat menimbulkan kegaduhan akibat disinformasi tentang covid-19.

Islam jelas memberikan ajaran bagaimana orang untuk memberikan informasi/berita yang benar (berkata benar) dan anjuran untuk melakukan klarifikasi/meneliti kebenaran (berita/informasi) yang didapatkan. Hal tersebut jika dilanggar akan mendapatkan balasan/konsekuensi yang telah diperingatkan oleh Allah swt.

\section{d. Berserah Diri Hadapi Pandemi}


Sudah menjadi kehendak Allah bahwa dalam kehidupan ini akan ada musibah, seperti dalam firman Allah surah Al-Hadid:22-23:

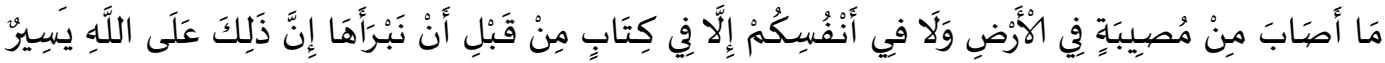

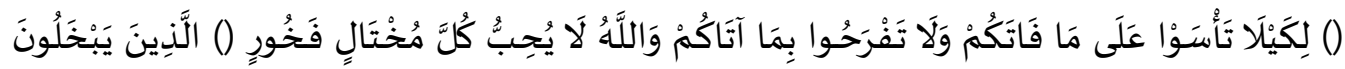

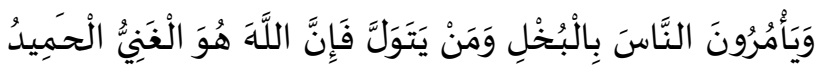

"Tiada suatu bencanapun yang menimpa di bumi dan (tidak pula) pada dirimu sendiri melainkan telah tertulis dalam kitab (Lauhul Mahfuzh) sebelum Kami menciptakannya. Sesungguhnya yang demikian itu adalah mudah bagi Allah. Kami jelaskan yang demikian itu) supaya kamu jangan berduka cita terhadap apa yang luput dari kamu, dan supaya kamu jangan terlalu gembira terhadap apa yang diberikan-Nya kepadamu. Dan Allah tidak menyukai setiap orang yang sombong lagi membanggakan diri"

Ayat tersebut mengisyaratkan bahwa musibah yang terjadi termasuk covid-19 adalah kehendak Allah dengan peringatan agar tidak terlalu bersedih dan terlalu berbahagia atas apa yang diberikan Allah swt. Tentu, sebagai umat manusia diberikan kuasa untuk berusaha melewati ujian/cobaan yang menimpa dalam bentuk musibah, namun hal yang paling penting dalam hal usaha tersebut, endingnya adalah kembali kepada Allah, karena pada dasarnya musibah tersebut bertujuan untuk menguji keimanan hambaNya.

Pada surah lain, Allah swt berfirman:

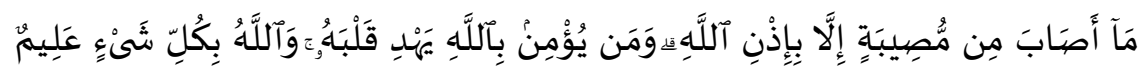

"Tidak ada sesuatu musibahpun yang menimpa seseorang kecuali dengan izin Allah; Dan barangsiapa yang beriman kepada Allah, niscaya Dia akan memberi petunjuk kepada hatinya. Dan Allah Maha Mengetahui segala sesuatu”. (Qs. At Taghabun:11)

Ayat di atas mengandung makna bahwa musibah yang terjadi di dunia ini adalah kehendak Allah, bagi umat manusia yang beriman lalu kena musibah, pada saat bersamaan musibah itu sejatinya menjadi petunjuk baginya dan akhirnya bisa menerima musibah yang menimpanya.

Kemudian Allah memerintahkan untuk bersabar ketika mendapatkan musibah dan menyerahkan sepenuhnya kalau musibah itu dari Allah, untuk itu kembalikan kepada Allah, seperti firmanNya dalam surah Albaqarah ayat 155-157:

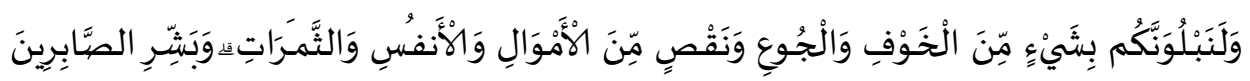

"Dan Kami pasti akan menguji kamu dengan sedikit ketakutan, kelaparan, kekurangan harta, jiwa, dan buah-buahan. Dan sampaikanlah kabar gembira kepada orang-orang yang sabar". (ayat 155) 


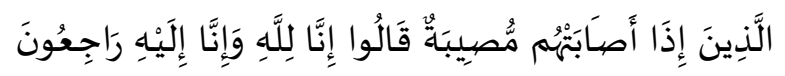

“(yaitu) orang-orang yang apabila ditimpa musibah, mereka berkata "Inna lillahi wa inna ilaihi raji'un" (sesungguhnya kami milik Allah dan kepadaNyalah kami kembali)".( ayat 156)

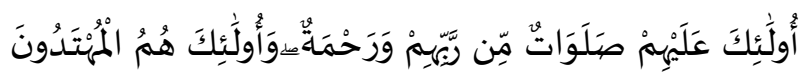

"Mereka itulah yang memperoleh ampunan dan rahmat dari Tuhannya, dan mereka itulah orang-orang yang mendapat petunjuk”.( ayat 157).

Dalam tafsir Ibnu Kasir dijelaskan; terkadang Allah memberi ujian dengan rasa bahagia dan pada waktu yang lain Allah juga memberi ujian dengan bentuk kesusahan, seperti rasa takut dan lapar. Firman Allah "Oleh karena itu, Allah merasakan kepada mereka pakaian kelaparan dan ketakutan” (An-Nahl:112). Karena orang yang pada kondisi lapar dan takut, ujian pada keduanya akan sangat terlihat jelas. Olehnya itu Allah berfirman, "Pakaian kelaparan dan ketakutan".

Berbagai hal tersebut dan yang semisalnya ialah bentuk ujian Allah kepada umatNya, bagi yang bersabar, maka Dia akan memberi pahala untuknya, dan bila ada yang putus asa karena ujian, maka Allah akan memberikan siksaan kepadanyasebab itu, di sini Allah berfirman, "Dan sampaikanlah berita gembira kepada orangorang yang sabar".

Selepas itu Allah menerangkan terkait orang-orang yang bersabar "yakni orang-orang yang jika dikasih musibah, mereka mengucap, "Innaa lillahi wa innaa ilaihi raaji 'un". Artinya, apabila musibah menimpa mereka, dengan ucapan tersebut, mereka menghibur diri nya serta mereka mengetahui bahwa diri mereka ialah milik Allah, Ia memperlakukan umatNya sesuai dengan kehendakNya. Selain itu, mereka juga mengerti bahwa Allah tidak menyia-nyiakan amalan mereka walau sebesar biji sawi di hari kiamat. Dan hal tersebut membuat mereka mengakui dirinya hanya seorang hamba di hadapan Allah swt, serta mereka akan kembali kepadaNya di akhirat kelak. Oleh sebab itu, Allah memberitahukan tentang apa yang diberikan kepada mereka, di mana Ia berfirman, "Mereka itulah yang mendapat keberkahan yang sempurna dan rahmat dari Rabb mereka". Artinya, pujian dari Allah Ta'ala atas mereka dan menurut Sa'id bin Jubair, "artinya, selamat dari adzab.

Firman Allah, "Dan mereka itulah orang-orang yang mendapat petunjuk". Amirul mukminin Umar bin Khatthab mengatakan, "Alangkah nikmatnya dua 
balasan itu, dan betapa menyenangkan (anugerah) tambahan itu. "Mereka itulah yang mendapat keberkahan yang sempurna dan rahmat dari Rabb mereka". Inilah dua balasan."Dan mereka itulah orang-orang yang mendapat petunjuk". Inilah tambahan. Mereka itulah orang-orang yang diberikan pahala-pahala dan diberikan pula tambahan ${ }^{40}$.

Berdasarkan dalil dalil tersebut, Allah mempunyai kehendak Nya sendiri dalam memberikan ujian, apakah itu berupa kebahagiiaan ataupun rasa takut dan kelaparan. Seperti misalnya kasus Covid-19 yang saat ini menimpa seluruh dunia termasuk Indonesia, menunjukkan bahwa kehendak Allah untuk memberikan ujian kepada hambanya berupa ketakutan ketakutan dan kehilangan jiwa (nyawa) melalui covid-19 benar adanya. Untuk itu Allah menghendaki kepada umatnya untuk sabar dalam menghadapi ujian, termasuk dalam menghadapi virus corona dan mengembalikan semuanya bahwa semua itu dari Allah dan akan kembali kepada Allah. Maka orang orang yang sabar dalam menghadapi ujian akan mendapatkan petunjuk berupa keberkahan yang sempurna dan rahmat serta pahala.

\section{Penutup}

Al-qur'an merupakan petunjuk untuk umat Islam dalam mengarungi kehidupan, tidak satupun luput dalam cakupan Al-Qur'an, termasuk salah satunya ajaran tentang pentingnya persatuan seperti dalam surah AL Imran: 103. Makna persatuan yang terkandung dalam surah tersebut seperti dalam tafsir Al-Ibnu Kasir, Al-Misbah, dan AlQurtubi, menyiratkan kesamaan pandangan bahwa umat manusia diperintahkan untuk bersatu padu dan dilarang bercerai berai, apabila bercerai berai segeralah kembali ke tali (agama) Allah.

Persatuan seperti dalam surah Al Imran: 103 sangat relevan, sekiranya jika diimplementasikan dalam penanganan covid-19 saat ini yang masih terus dibayang bayangi ketidak patuhan masyarakat dalam mengikuti anjuran pemerintah. Semangat persatuan sebagai doktrin agama bagi umat islam perlu ditanamkan dalam tiap diri manusia sebagai sebuah keimanan yang harus dipatuhi. Selain itu, semangat persatuan telah dicontohkan dalam beberapa rentetan sejarah yang membuahkan hasil, bahkan ulama juga jauh jauh hari telah mengingatkan pentingnya persatuan.

\footnotetext{
${ }^{40}$ Tafsir Ibnu Kasir Surah Al Baqarah ayat 155-157, hlm 303-306.
} 
Dalam konteks penangan pandemic covid-19, nilai persatuan dalam surah Al-Imran ayat 103 dapat diimplementasikan dengan menanamkan rasa persatuan menjadi sebuah keyakinan dalam diri untuk menghadapi pandemic, bersatu padu dan taat pada anjuran anjuran pemerintah dalam menghadapi pandemic, dan bersatu dalam menangkal hoax \& pengendalian diri dari hal hal yang dapat memperuncing penanganan pandemic covid-19.

\section{DAFTAR PUSTAKA}

Adams, C. (2014). Bung Karno Penyambung Lidah Rakyat Indonesia, Terj: Syamsu HadiEdisi Revisi. Media Pressindo dan Yayasan Bung Karno.

Agustino, L. (2020). Analisis Kebijakan Penanganan Wabah Covid-19: Pengalaman Indonesia,. Jurnal Borneo Administrator, 16(2).

AL-Bukhari, M. bin I. (n.d.). Shahih al-Bukhari. Dar Thauq al-Najat.

Al-Qurthubi, M. (2006). Al-Jami Li Ahkamil Qur'an. Al-Resalah Publishers.

An-Naisaburi, M. (2006). Shohih Muslim. Dar At-Thaybah.

Daud. (2020). Pandemic Covid-19: Persoalan dan Refleksi di Indonesia; Sosial Distancing dan Budaya Kita,. Yayasan Kita Menulis.

Dimasyqi, A. I. A. F. I. I. K. A. (n.d.). Tafsir Ibnu Kasir, Juz 4, Surah Al Imran 92 s.d An Nisa 23. Sinar Baru Algesindo.

Jannah, S. M. (2020). Antisipasi Corona, Jokowi Sebut Kerja, Belajar \& Ibadah dari Rumah. https://tirto.id/antisipasi-sebut-kerja-belajar-ibadah-dari-rumah-eFfr

Kompas. (2020). ronologi-dan-urutan-munculnya-6-orang-positif-virus-corona-diindonesia. KOMPAS.Com.

Limited, T. E. I. U. (2020). The EIU tracker ranks the quality of policy responses to the pandemic given countries' risk profiles: Assessing the quality of OECD countries' responses to Covid-19.

Maulana, L. (2017). Kitab Suci Dan Hoax: Pandangan Alquran Dalam Menyikapi Berita Bohong. Wawasan: Jurnal Ilmiah Agama Dan Sosial Budaya, 2(2).

Nizar, M. C. (2017). Pemikiran KH. Hasyim Asy'ari tentang Persatuan. Endogami: Jurnal Ilmiah Kajian Antropolog, 1(1).

Nurpratiwi, M. R. E. dan S. (2021). Hubungan Keberagamaan dan Perilaku Altruistik Mahasiswa. Al-Afkar, 4(1), 83-97. https://doi.org/https://doi.org/10.31943/afkarjournal.v4i1.181

RI, B. (2020). Perilaku Masyarakat Ditengah Pandemi Covid-19. BPS.

Sensusiyati, R. N. R. \&. (2020). Analisis Berita Hoax Covid -19 Di Media Sosial Di 
Indonesia. Intelektiva : Jurnal Ekonomi, Sosial \& Humaniora, 1(2).

Shihab, M. Q. (2005). Tafsir Al Misbah: Pesan, Kesan dan Keserasian Al Qur'an. Lentera Hati.

Suci Nurpratiwi, Muhamad Ridwan Effendi, A. (2021). Improving Religious Literacy Through Islamic Religious Education Course Based On The Flipped Classroom. Istawa, 6(1), 16-29. https://doi.org/http://dx.doi.org/10.24269/ijpi.v6i1.3107

Wardani, B. (4 C.E.). The Kiwi Way: Strategi Eliminasi COVID-19 Selandia Baru. Global Startegis, 2.

Widodo, S. K. (2012). Memaknai Sumpah Pemuda di Era Reformasi. Humanika, 16(9).

Yassa, S. (2018). Media Publikasi Pendidikan Pancasila dan Kewarganegaraan. Jurnal Citizenship, 1(1). 